\title{
THE ROLE OF LEADERSHIP SOFT SKILLS IN PROMOTING THE LEARNING ENTREPRENEURSHIP
}

\begin{abstract}
Zana Majed Sadq
Department of Management, Faculty of Humanities and Social Sciences, Koya University, Iraq, and Visiting Lecturer at Lebanese French University, Iraq

zana.sadq@koyauniversity.org
\end{abstract}

\section{Original Scientific Paper doi:10.5937/jouproman7-20122}

\begin{abstract}
This study is interested in identifying the role of leadership soft skills that its dimensions comprised of (communication skills, initiative skills, training skills, and team building skills)according to the views of the Members of College Councils in a sample of colleges of Salahaddin University, Erbil/ Iraq in promoting learning entrepreneurship that its dimensions comprised of (leadership efficiency, Entrepreneurship intention, and daring behavior) through a field testing study variables that based on the theoretical and methodological frameworks. A survey questionnaire has been designed and distributed to members of the colleges' Councils of a number of colleges of Salahaddin University that numbered 41 respondents in order to verify study hypotheses that have been developed to address the study problem. The most important results that the study reached are there is a positive correlation and an impact of leadership soft skills and learning entrepreneurship collectively and individually. Based on the results, this study presented a set of recommendations such as the necessity to increase the awareness of individuals in organizations about the importance of leadership soft skills, and seek to exploit and embrace untapped opportunities along with creating the accurate climate to work as a team in order to improve the performance and achievement goals.
\end{abstract}

Keywords: Leadership soft skills, communication skills, initiative skills, training skills, team building skills, and learning entrepreneurship.

\section{Introduction:}

Leadership is one of the most important organizational elements that contemporary organizations need to survive and continue in light of the current developments and dynamic changes accelerated. These conditions have increased the need for leadership styles with personal skills in addition to the capacity to employ its potential for action in order to build positive relationships among the employees to face contemporary challenges and converting from a hierarchical leadership model to a soft leadership model that focuses on collaborative work and positive interaction with subordinates.

The soft skills are vital skills for effective performance in the 21 st century. Soft skills have become a new area of leadership now and in the future and it is a priority for high performance since it considers being an important and effective element in the success of any organization. It also has a significant impact on the behavior of followers towards discipline, commitment and belonging to the organization in which they work in addition to achieve its desired goals.

Learning entrepreneurship is an important and necessary topic that leading individuals learn the skills and competencies needed to work in leading organizations. 
Moreover, gaining knowledge that helps them identifying and exploit new job opportunities converting them into business concepts that add value and generate revenue also to benefit from the organization and management of leading organizations. Thus, it is promoting, developing and achieving leading performance.

Based on the above, this study is intended to identify the role of soft leaderships' soft skills in promoting learning entrepreneurship through four chapters. The first chapter is dealt with the study methodology. The second chapter analyzes and presents the reviewing literature. The third included the field study. The final chapter presents a discussion and recommendation based on the results that this study will reached.

\section{Chapter one: study methodology}

\section{Study problem:}

The leadership has a prominent role in all organizational areas, as it affects primarily the degrees of belonging, loyalty and leading organizations learning entrepreneurship. The soft skills of leadership are contemporary skills that have the ability to influence leadership efficiency and self-efficacy that represents the essence of leading learning entrepreneurship process. In light with this, this study presents the study problem by raising the following questions:

1. What is the level of perceptions of the members of the college councils at the University of Salahaddin about the soft skills of leadership that its dimensions include (communication skills, initiative skills, training skills, and team building skills).
2. What is the level of perceptions of the members of the college councils at the University of Salahaddin about the learning entrepreneurship that its dimensions include (leadership efficiency, entrepreneurship intention, and daring behavior).

3. Is there a correlation between leaderships' soft skills and learning entrepreneurship?

4. What is the effect of leadership soft skills on the dimensions of learning entrepreneurship in the organization under investigation?

\section{Study objectives:}

The objectives of this study are reflected in the following:

1. Building a theoretical framework for the study variables through the review on the relevant sources.

2. Diagnosis the levels of leadership soft skill and dimensions of learning entrepreneurship.

3. Determine the nature of the correlation and the effect between the study variables.

\section{The significance of study:}

1. Describing the importance of leaderships' soft skills to the members of the collage councils at the university of Salahaddin/ Erbil.

2. This study contributes to determining the correlation and the effects between the study variables (leadership soft skills and learning entrepreneurship).

3. Building a model hypothesis for the study and attempt to test it statistically.

4. Reaching outcomes and conclusions and based on the results presenting a set of recommendations that service the University of Salahaddin. 
The study theoretical framework:

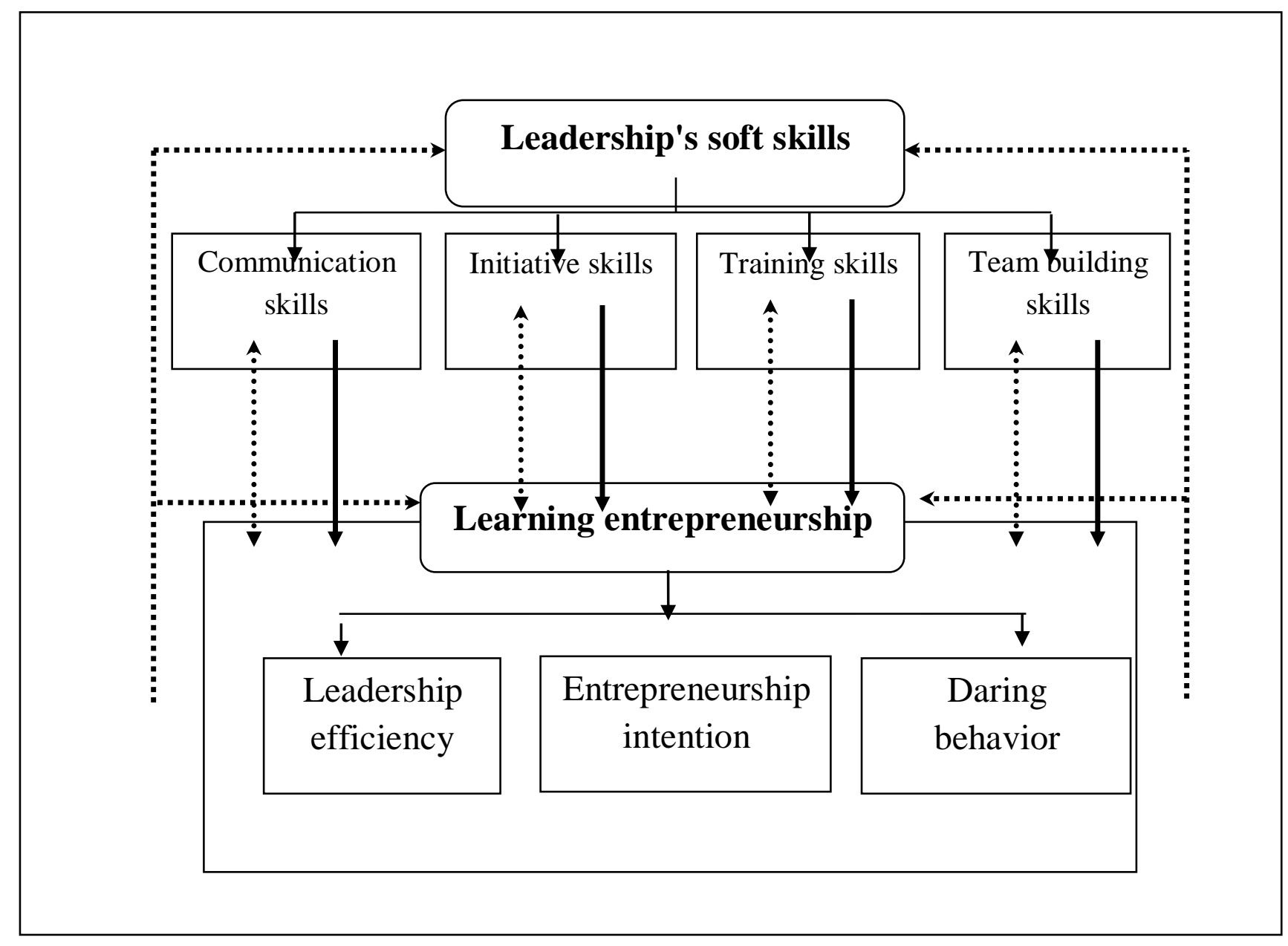

Figure (1) the study theoretical framework

The first main Hypothesis: there is a statistically significant correlation between leadership soft skills and learning entrepreneurship. The following hypotheses are derived from the first main hypothesis:

1. There is a statistically significant correlation between communication skills and learning entrepreneurship.
2. There is a statistically significant correlation between initiative skills and learning entrepreneurship.

3. There is a statistically significant correlation between training skills and learning entrepreneurship.

4. There is a statistically significant correlation between team building skills and learning entrepreneurship. 
The second main Hypothesis: there is a statistically significant effect of leadership soft skills on learning entrepreneurship. The following hypotheses are derived from the second main hypothesis:

1. There is a statistically significant effect of communication skills on learning entrepreneurship.

2. There is a statistically significant effect of initiative skills on learning entrepreneurship.

3. There is a statistically significant effect of training skills on learning entrepreneurship.

4. There is a statistically significant effect of team building skills on learning entrepreneurship.

Study population and sample:
The field study represents the University of Salahaddin in the Erbil city, Kurdistan Region /Iraq. The study population consist all the members of the collage councils represented by the deans, heads of departments and assistants of the deans in all collage of University of Salahaddin that includes (104) academic leaders in (14) colleges, (14) Dean, (14) assistants dean and (76) Head of Departments. However, the study sample consists of (61) academic leaders in seven selected collages of University of Salahaddin. The questionnaire was randomly distributed $(41 \%)$ were retrieved that consist $(61 \%)$ of the total study population. Table (1) shows the distribution of the forms by colleges.

Table (1)distribution of individuals by colleges

\begin{tabular}{|c|l|c|c|c|}
\hline & \multicolumn{1}{|c|}{ The Colleges } & $\begin{array}{c}\text { Number of } \\
\text { distributed } \\
\text { forms }\end{array}$ & $\begin{array}{c}\text { Retrieved } \\
\text { forms }\end{array}$ & Percentage \\
\hline $\mathbf{1}$ & $\begin{array}{l}\text { Administration } \\
\text { and Economics }\end{array}$ & 8 & 6 & 14.6 \\
\hline $\mathbf{2}$ & Agriculture & 9 & 6 & 14.6 \\
\hline $\mathbf{3}$ & Literature & 10 & 8 & 19.5 \\
\hline $\mathbf{4}$ & Languages & 9 & 6 & 14.6 \\
\hline $\mathbf{5}$ & Basic Education & 8 & 7 & 17.2 \\
\hline $\mathbf{6}$ & Education & 11 & 5 & 12.2 \\
\hline $\mathbf{7}$ & Fine arts & 6 & 3 & 7.3 \\
\hline \multicolumn{2}{|r|}{ Total } & 61 & 41 & $100 \%$ \\
\hline
\end{tabular}

The demographic characteristics of the individuals interviewed, Table (2) shows it as following:

Gender: The percentage of males' represents $(87.8 \%)$ of total study sample, while females' represents $(12.2 \%)$ of total study sample.
Age: The highest group is (45 years and older) with a percentage of $78.0 \%$, followed by the group of (45-36 years) with a percentage of $22.0 \%$.

Academic qualification: the results of Table (2) show that the majority of the respondents are holders of the doctorate degree with the percentage of $(87.7 \%)$. 
However, the percentage of the master's degree holders is $(12.2 \%)$.

The scientific title: the results of Table (2) show that the majority of the respondents are holders of the title of assistant professor with a percentage of $(56.1 \%)$. Comes second the title of teacher with
(36.6\%), while the percentage of holders of the title of assistant teacher is (7.3\%).

Total years of experience: it is noted from Table (2) that the percentage of the respondents according to the group (20-11 years) of experience with $(43.9 \%)$ is the highest rate compared to other groups. the group (21-30) comes second with (31.7\%).

Table (2)distribution of respondents according to their demographic characteristics

\begin{tabular}{|c|c|c|c|c|}
\hline & $\begin{array}{l}\text { Demographic } \\
\text { characteristics }\end{array}$ & Groups & Frequencies & Percentages \\
\hline \multirow{2}{*}{1} & \multirow[t]{2}{*}{ Gender } & Male & 36 & 87.8 \\
\hline & & Female & 5 & 12.2 \\
\hline \multirow{4}{*}{2} & \multirow{4}{*}{ Age } & Less than 25 years & $\mathbf{0}$ & $\mathbf{0 . 0}$ \\
\hline & & 26-35 years & $\mathbf{0}$ & 0.0 \\
\hline & & $36-45$ years & 9 & 22.0 \\
\hline & & More than 45 years & 32 & 78.0 \\
\hline \multirow{2}{*}{3} & \multirow{2}{*}{$\begin{array}{l}\text { Academic } \\
\text { qualification }\end{array}$} & MSc. & 36 & 87.8 \\
\hline & & PhD. & 5 & 12.2 \\
\hline \multirow{4}{*}{4} & \multirow{4}{*}{ The scientific title } & Assistant lecturer & 3 & 7.3 \\
\hline & & Lecturer & 15 & 36.6 \\
\hline & & Assistant professor & 23 & 56.1 \\
\hline & & Professor & 0 & 0.0 \\
\hline \multirow{4}{*}{5} & \multirow{4}{*}{$\begin{array}{l}\text { Total years of } \\
\text { experience }\end{array}$} & $1-10$ years & $\mathbf{0}$ & 0.0 \\
\hline & & 11-20 years & 18 & 43.9 \\
\hline & & 21-30 years & 13 & 31.7 \\
\hline & & 31-40 years & 10 & 24.4 \\
\hline
\end{tabular}

\section{Questionnaire instruments:}

The five dimensional Likert scale was used, which it considered to be one of the most widely used measuring tools in addition it is easy and accurate at the same time. The researcher promised the mean range between (1-2.49) as level of low perceptions. Mean range between (2.53.49) as medium level of perceptions, and high level of perceptions if the mean range is between (3.5- 5) 
Table (3) questionnaire instruments

\begin{tabular}{|c|c|c|c|c|}
\hline 5 & 4 & 3 & 2 & 1 \\
\hline $\begin{array}{c}\text { Strongly } \\
\text { agree }\end{array}$ & Agree & Uncertain & Disagree & $\begin{array}{c}\text { Strongly } \\
\text { disagree }\end{array}$ \\
\hline
\end{tabular}

Study Reliability:

The coefficient of Cronbach's Alpha (Reliability) for leadership soft skills and learning entrepreneurship according to the table below are equal to
(.885) (.847) respectively. Besides, for the whole questionnaire is equal to (.918). These results reflect that the study variables as well as the whole items of the questionnaire have a high reliability.

Table (4) Cronbach's Alpha value for the study variables

\begin{tabular}{|l|c|c|}
\hline \multicolumn{1}{|c|}{ Variables } & $\begin{array}{c}\text { Cronbach's Alpha } \\
\text { value }\end{array}$ & No. Of items \\
\hline Leadership soft skills & .885 & 20 \\
\hline Learning entrepreneurship & .847 & 15 \\
\hline Whole questionnaire & .918 & 35 \\
\hline
\end{tabular}

\section{Chapter two: Literature review}

\section{Leadership soft skills:}

Skills are described as the ability to develop unique and effective methods to accomplish the work according to the knowledge and experience of the individuals (Abdullah and Abdul Rahman, 2012, 408). The source of the word soft comes from the non-traditional obtaining skills that their result is considered to be difficult to measure (Simpson,2006:10). Besides, through a brief description of skills and softness and based on what researchers have addressed to the concept of soft skills, it can be defined as those skills that focus on It can be defined as those skills that focus on persuade and influence others (Rao, 2013:145). On his part (Hajjaj, 2008, 12) defined it as it is the attributes, characteristics and personal abilities individuals acquire it and contribute to enhancing interaction with others. (Rongraung et al,2011, 957) agreed with the above and they farther defined soft skills as those skills that helps to build relationships and communication among individuals and it $\mathrm{t}$ can be acquired and developed through learning and training. Balachander and Jayam $(2015,230)$ refer to soft skills as skills with social characteristics determines the difference degree between the individuals. Based on the above, the researcher define the soft skills as intangible personal abilities determines the strength and influence of individuals since it is consider being abilities and behaviors more than knowledge and technology.

Leadership soft skills, they are skills focused on empathy with a focus on humanitarian aspects in encouraging and persuading others (Marques,2013, 163). 
Al-Mahmada $(2015,37)$ indicates that leaderships' soft skills they are the behavioral skills of the leader towards subordinates to provide the best performance levels to achieve the desired goals. Rao $(2015,4)$ states that leadership soft skills is a set of personal and behavioral abilities of the leader that help to influence the employees. Hence, the researcher confirms that leadership soft skills are a set of behaviors adopted by leaders that affect the behavior and attitudes of employees.

\section{The significance of leadership soft skills:}

Soft skills are considered imperative in the current rapid change and complexity world. The leaderships' solid skills or socalled technical skills are no longer sufficient for the success of leaders in the face of change in today's environment (Shahid, 2012, 486). (Hajjaj, 2014: 14), (Brungardt, 2011, 31), (Azim et al, 2010, 387), and (Rao, 2013, 145) pointed the following points as the significance of leadership soft skills:

1. Contribute to reducing the negative conflict between the employees.

2. Helps to reduce work stress.

3. Leads to build a kind of balance between the employees' personal and functional lives.

4. Reinforce and strengthen relationships between employees.

5. Increase communication efficiency.

6. Contribute to obtain and consolidation of professional skills.

7. Leads to employees' commitment and their participation in decision-making.

\section{Types of leadership soft skills:}

Researchers presented many types of leaderships' soft skills and they presented different detentions to the leaderships' soft skills. Despite this disparity, many researchers agreed (communication skills, initiative skills, training skills, and team building skills) as types of leaderships' soft skills (Somerset,2013), (Brungardt, 2011), (Shahid, 2011), (Tang et al, 2013), (Rongraung et al, 2014), and (Awan et al, 2015).

Communication skills: active communication is one of the most important leaderships' soft skills that include effective listening and feedback (Levasseur, 2013, 566). Nikitina and Furuoka (2011, 33) refers that communication skills include oral skills as well as written skills. (Cole, 1999, 9) emphasizes that those leader who fails to communicate with the employees reflected on their trust and loyalty resulting in poor performance. Shahid $(2011,194)$ presented a range of skills such as speaking skills, writing, listening, and responding as types of communication skills.

Initiative skills: the initiative skills is a humanitarian activity practiced by leaders, leads to the introduction of something new takes a variety of forms and their adoption leads to multiple benefits (Akrawi, 2002, 130). Zedan (2007, 239) confirms that the initiative skills is a necessary skill for leaders and is one of the soft skills that convert ideas into reality.

Training skills: Shahid (2011, 206) emphasizes that the leaders' focus on the employees training and development is the core of the leader's work and responsibilities. Kolzow $(2014,283)$ agrees with the above and he further states that the employees training and development is the core tasks of the leader's effort, and supporting leaders' soft skills to the training and education program will enhance the desired behaviors in the organization. 
Team building skills: Mckenna (2000: 348) points out that team building skills involves the ability to motivate members to commit voluntarily. Awan et al., (2015, 31) emphasizes that the successful leader develops the team and builds a strong relationship with team members in a positive way, and the leaders are responsible for creating a suitable atmosphere for the team to achieve coordination among the employees.

\section{Learning entrepreneurship:}

The last period achieved a major development in search into the nature of the learning entrepreneurship process. But the field search still needs more research and study. The research was about how individuals obtain knowledge in addition to activating the behaviors in identifying the opportunity and recognition according to the organization and management of organizations (Abrar et al,2011, 3). After reviewing the literature on learning entrepreneurship, there wasn't a specific and comprehensive definition to learning entrepreneurship, because this term is transmitted through different cultures. Gibb (2001, 105) defined the learning entrepreneurship as the main engine of organizational life that emerge from the entrepreneurial environment. Kraeger (2002, 79) defined the learning entrepreneurship as a model of knowledge, cognition and decision-making during the stages of entrepreneurship process. Cope $(2005,15)$ believes that the learning entrepreneurship is a dynamic process that includes stages, processes and characteristics. However, Rae (2006, 88) turned a different direction in his definition of learning entrepreneurial as he expressed learning entrepreneurial as the product of personal variables along with environmental learning. Further, Abrar \& Know (2012, 810) defined learning entrepreneurial as it is the process of recognizing the opportunity and social interaction along with a wide range of elements to organize and manage projects. Based on the above, the researcher defines learning entrepreneurial as a process of acquiring knowledge in all fields and employs this knowledge in business management by anticipating opportunities before competitors and reducing the negative effects of risk.

\section{The significance of learning entrepreneurship:}

The significance of learning entrepreneurial can be illustrated as the following (Moustaghfir\&Sirca,2010, 5):

1. Promote entrepreneurial behavior and encourage entrepreneurs to engage in entrepreneurship.

2. Assisting to select the right methods of learning and support the entrepreneurial objectives.

3. Contribute to building the capacity of entrepreneurs.

4. Assist in the growth and development of entrepreneurs.

5. Improving the effectiveness of entrepreneurial and entrepreneurial practices.

6. Contribute to the development of knowledge and the experiences of the entrepreneurial through linking knowledge to abilities and thinking.

\section{The dimensions of learning entrepreneurship:}

The dimensions of learning entrepreneurship can be shows as the following (Inyang, 2009, 65), (Dermol, 2010, 27), (Samah and Murad, 2010, 7), and (Sarwoko et al, 2013, 32): 
Leadership efficiency: represents individual characteristics that include behavior that allows the entrepreneur to succeed at work as well as the abilities, motives, attitudes and skills that help $\mathrm{him} /$ her to reach the leading performance

Entrepreneurship intention: intention is a state of mind directs the individuals towards a specific goal and purpose, and express to a conscious representation of the desired goal. Entrepreneurship intention is the main source of entrepreneurship behavior and creating the entrepreneurship base.

Daring behavior: is a behavior that supports change and stimulates creativity. This behavior is characterized by the continuous search for opportunities. It helps to innovate and change through relying on flexible technology. Further, risk tolerance is a key characteristic of this behavior.

\section{Chapter three: results and outcomes}

The results of descriptive statistics are presented below that include the value of mean, standard deviations, and the rate of importance.

\section{Description and diagnosis of leadership soft skills dimensions:}

Table (5) shows the means' general average of leadership soft skills that reached (4.313), with a rate of importance reached $(86.28 \%)$. Given a look to the leaderships' soft skills dimensions, there is a high level in the general averages of all dimensions that the responses reflect the awareness of study sample to the importance role leaderships' soft skills dimensions represented by (communication skills, initiative skills, training skills, and team building skills) in promoting learning entrepreneurship.
1. Communication skills: Table (5) shows the values of the mean, standard deviations and the rate of importance to the communication skills questions respondents' view. Its five questions reflect a general mean of (4.332), with a general rate of importance reached $(86.64 \%)$. These results indicating that the leadership communication skills are receiving a high level of attention at the University of Salahaddin. Item (X4) comes first that states (I have the ability to communicate my thoughts to others.) with a mean of (4.47) and rate of importance reached (89.4\%). However, the item (X5) comes last that states (I pay attention to messages that are directed by others accurately.) with a mean of (4.06) and rate of importance reached $(81.2 \%)$.

2. Initiative skills: the five questions of initiative skills reflect a general mean of (4.13), with a general rate of importance reached $(82.68 \%)$. These results indicating that the initiative skills are receiving a high level of consideration at the organization under study. Item (X8) comes first that states (I focus on proactive initiative rather than waiting and responding to events.) with a mean of (4.53) and rate of importance reached $(90.6 \%)$. On the other hand, the item (X7) comes last that states (I take responsibilities to the risks in order to apply new ideas.) with a mean of (3.34) and rate of importance reached $(66.8 \%)$.

3. Training skills: the five questions of training skills reflect a general mean of (4.29), with a general rate of importance reached (85.8\%). These results indicating that the training skills are receiving a high level of consideration according to the respondents answer. 
Item (X14) comes first that states (I encourage others to complete research and studies.) with a mean of (4.38) and rate of importance reached $(87.6 \%)$. In contrast, the item (X13) comes last that states (I develop staff ability for obtain different knowledge.) with a mean of (4.19) and rate of importance reached $(83.8 \%)$.

4. Team building skills: the five questions of team building skills reflect a general mean of (4.5), with a general rate of importance reached $(90 \%)$. These results indicating that the team building skills are receiving a high level of consideration according to the study sample answers. Item (X19) comes first that states (I motivate voluntary commitment to achieving goals.) with a mean of (4.75) and rate of importance reached (95\%). However, the item (X20) comes last that states (I adopt the teamwork approach as a means of improving performance.) with a mean of (4.25) and rate of importance reached (85\%).

Table (5) means, standard deviations, and rate of importance to Leadership soft skills questions

\begin{tabular}{|c|c|c|c|c|c|}
\hline & Leadership soft skills questions & Mean & $\begin{array}{c}\text { St. } \\
\text { Deviatio } \\
n\end{array}$ & $\begin{array}{c}\text { Rate of } \\
\text { importan } \\
\text { ce }\end{array}$ & $\begin{array}{c}\text { T } \\
\text { Value }\end{array}$ \\
\hline $\mathbf{X 1}$ & Iuse phrases and movements to convey ideas. & 4.28 & .581 & 85.6 & $\begin{array}{c}12.47 \\
2\end{array}$ \\
\hline $\mathbf{X} 2$ & Communicate in writing with college staff & 4.44 & .564 & 88.8 & $\begin{array}{c}14.40 \\
8\end{array}$ \\
\hline $\mathbf{X 3}$ & $\begin{array}{l}\text { I have the ability to make dialogue, debate } \\
\text { and exchange views. }\end{array}$ & 4.41 & .756 & 88.2 & $\begin{array}{c}10.52 \\
2\end{array}$ \\
\hline X4 & $\begin{array}{l}\text { I have the ability to communicate my } \\
\text { thoughts to others. }\end{array}$ & 4.47 & .718 & 89.4 & $\begin{array}{c}11.57 \\
6\end{array}$ \\
\hline X5 & $\begin{array}{l}\text { I pay attention to messages that are directed } \\
\text { by others accurately. }\end{array}$ & 4.06 & .801 & 81.2 & 7.506 \\
\hline \multicolumn{2}{|r|}{ General average of communication skills } & 4.332 & .684 & 86.64 & 11.296 \\
\hline X6 & $\begin{array}{l}\text { I initiative to rely on new methods of } \\
\text { academic work. }\end{array}$ & 4.25 & .729 & 85 & 9.944 \\
\hline $\mathbf{X} 7$ & $\begin{array}{l}\text { I take responsibilities to the risks in order to } \\
\text { apply new ideas. }\end{array}$ & 3.34 & 1.035 & 66.8 & 1.878 \\
\hline $\mathbf{X 8}$ & $\begin{array}{l}\text { I focus on proactive initiative rather than } \\
\text { waiting and responding to events. }\end{array}$ & 4.53 & .718 & 90.6 & $\begin{array}{c}12.06 \\
9\end{array}$ \\
\hline X9 & I solve the problems that I face in a new way. & 4.27 & .634 & 85.4 & $\begin{array}{c}11.42 \\
8\end{array}$ \\
\hline $\begin{array}{c}\mathbf{X 1} \\
\mathbf{0}\end{array}$ & $\begin{array}{l}\text { I seek to exploit and build untapped } \\
\text { opportunities. }\end{array}$ & 4.28 & .683 & 85.6 & $\begin{array}{c}10.60 \\
9\end{array}$ \\
\hline \multicolumn{2}{|r|}{ General average of initiative skills } & 4.13 & .759 & 82.68 & 9.185 \\
\hline
\end{tabular}




\begin{tabular}{|c|c|c|c|c|c|}
\hline $\begin{array}{c}\mathrm{X1} \\
1\end{array}$ & I educate college staff to teach new skills. & 4.22 & .706 & 84.4 & 9.760 \\
\hline $\begin{array}{c}\mathrm{X1} \\
2\end{array}$ & $\begin{array}{l}\text { I encourage others to participate in } \\
\text { conferences. }\end{array}$ & 4.33 & .701 & 86.6 & $\begin{array}{c}10.84 \\
9\end{array}$ \\
\hline $\begin{array}{c}\mathrm{X1} \\
3\end{array}$ & $\begin{array}{l}\text { I develop staff ability for obtain different } \\
\text { knowledge. }\end{array}$ & 4.19 & 644 & 83.8 & $\begin{array}{c}10.42 \\
4\end{array}$ \\
\hline $\begin{array}{c}X 1 \\
4\end{array}$ & $\begin{array}{l}\text { I encourage others to complete research and } \\
\text { studies. }\end{array}$ & 4.38 & .707 & 87.6 & $\begin{array}{c}11.00 \\
0\end{array}$ \\
\hline $\begin{array}{c}\mathrm{X1} \\
5\end{array}$ & $\begin{array}{l}\text { The performance of the staff at the college } \\
\text { evaluated objectively. }\end{array}$ & 4.34 & .701 & 86.8 & $\begin{array}{c}10.84 \\
9\end{array}$ \\
\hline \multicolumn{2}{|r|}{ General average of training skills } & 4.29 & .691 & 85.8 & 10.576 \\
\hline $\begin{array}{c}\mathrm{X} 1 \\
6\end{array}$ & I encourage others to work as a team & 4.59 & .756 & 91.8 & $\begin{array}{c}11.92 \\
5\end{array}$ \\
\hline $\begin{array}{c}\mathrm{X} 1 \\
7\end{array}$ & $\begin{array}{l}\text { I seek to create the right environment for } \\
\text { working as a team. }\end{array}$ & 4.50 & .718 & 90 & $\begin{array}{c}11.81 \\
1\end{array}$ \\
\hline $\begin{array}{c}\mathbf{X 1} \\
8\end{array}$ & $\begin{array}{l}\text { I focus on committee recommendations and } \\
\text { task force to ensure access to collective } \\
\text { decisions. }\end{array}$ & 4.41 & .712 & 88.2 & $\begin{array}{c}11.17 \\
1\end{array}$ \\
\hline $\begin{array}{c}\mathbf{X 1} \\
9\end{array}$ & $\begin{array}{l}\text { I motivate voluntary commitment to } \\
\text { achieving goals. }\end{array}$ & 4.75 & 672 & 95 & $\begin{array}{c}14.73 \\
1\end{array}$ \\
\hline $\begin{array}{c}\mathbf{X} 2 \\
\mathbf{0}\end{array}$ & $\begin{array}{l}\text { I adopt the teamwork approach as a means of } \\
\text { improving performance. }\end{array}$ & 4.25 & 672 & 85 & $\begin{array}{c}10.52 \\
2\end{array}$ \\
\hline & General average of team building skills & 4.5 & .706 & 90 & 12.032 \\
\hline & General average of Leadership soft skills & 4.313 & .71 & 86.28 & 10.77 \\
\hline
\end{tabular}

\section{Description and diagnosis of learning entrepreneurship dimensions:}

Table (6) illustrates the means' general average of learning entrepreneurships' questions that reached $(4.14)$, with a rate of importance reached (86\%). Given a look to the learning entrepreneurship dimensions, there is a high level in the general averages of all dimensions that reflects the awareness and interest of the university administration in the importance of the learning entrepreneurship dimensions in addition seeking to strengthen them such as attention to the scientific behavior and employees' experience to achieve outstanding results as well as working to adapt with environmental changes.

1. Leadership efficiency: Table (6) shows the values of the mean, standard deviations and the rate of importance to the leadership efficiency questions according to the respondents' view. Its five questions reflect a general mean of (4.37), with a general rate of importance reached $(87.44 \%)$. These results indicating that the leadership efficiency is receiving a high level of attention at the University of Salahaddin. 
Moreover, item (Y3) comes first that states (Employees at the college have the ability to organize and execute business.) with a mean of (4.69) and rate of importance reached $(93.8 \%)$. However, the item (Y5) comes last that states (Employees at the college have the expertise needed to achieve unique achievements.) with a mean of (4.27) and rate of importance reached $(85.4 \%)$.

2. Entrepreneurship intention: Table (6) shows the values of the mean, standard deviations and the rate of importance to the entrepreneurship intention questions according to the respondents' view. Its five questions reflect a general mean of (4.18), with a general rate of importance reached $(83.6 \%)$. These results indicating that the entrepreneurship intention is receiving a high level of consideration at the University. Furthermore, item (Y10) comes first that states (I have the intention and the will to seek opportunities.) with a mean of (4.38) and rate of importance reached
$(87.6 \%)$. On the other hand, the item (Y7) comes last that states (I have the motivation to reach the desired results.) with a mean of (4.06) and rate of importance reached $(81.2 \%)$.

3. Daring behavior: table demonstrates the values of the mean, standard deviations and the rate of importance to the daring behavior questions according to the study sample view. Its five questions reflect a general mean of (3.89), with a general rate of importance reached $(77.8 \%)$. These results indicating that the daring behavior is receiving a high level of contribution to strengthen the learning entrepreneurships process. In addition, item (Y14) comes first that states (I adapt to all environmental factors and variables.) with a mean of (4.27) and rate of importance reached (85.4\%). In contrast, the item (Y11) comes last that states (I take the responsibilities to risk related to exploiting opportunities.) with a mean of (3.74) and rate of importance reached $(74.8 \%)$.

Table (6) means, standard deviations, and rate of importance to Learning entrepreneurships' questions

\begin{tabular}{|c|l|c|c|c|c|}
\hline & Learning entrepreneurships' questions & Mean & $\begin{array}{c}\text { St. } \\
\text { Deviatio } \\
\mathbf{n}\end{array}$ & $\begin{array}{c}\text { Rate of } \\
\text { importance }\end{array}$ & $\begin{array}{c}\text { T } \\
\text { Value }\end{array}$ \\
\hline Y1 & $\begin{array}{l}\text { The employees at the college has high } \\
\text { self-competence } \\
\text { outstanding activities }\end{array}$ to accomplish & 4.28 & .729 & 85.6 & 9.944 \\
\hline Y2 & $\begin{array}{l}\text { I concerned with the employees scientific } \\
\text { behavior to achieve outstanding results. }\end{array}$ & 4.31 & .693 & 86.2 & 10.71 \\
\hline Y3 & $\begin{array}{l}\text { Employees at the college have the ability } \\
\text { to organize and execute business. }\end{array}$ & 4.69 & .693 & 93.8 & 13.78 \\
\hline Y4 & $\begin{array}{l}\text { Employees at the college are willing to } \\
\text { participate in the training programs. }\end{array}$ & 4.31 & .693 & 86.2 & 10.71 \\
\hline
\end{tabular}




\begin{tabular}{|c|c|c|c|c|c|}
\hline Y5 & $\begin{array}{l}\text { Employees at the college have the } \\
\text { expertise needed to achieve unique } \\
\text { achievements. }\end{array}$ & 4.27 & .813 & 85.4 & 8.920 \\
\hline \multicolumn{2}{|r|}{ General average of leadership efficiency } & 4.37 & .724 & 87.44 & 10.81 \\
\hline Y6 & $\begin{array}{l}\text { I had the intention to prepare employees' } \\
\text { with entrepreneurship ideas. }\end{array}$ & 4.24 & .772 & 84.8 & 9.390 \\
\hline Y7 & $\begin{array}{l}\text { I have the motivation to reach the desired } \\
\text { results. }\end{array}$ & 4.06 & .619 & 81.2 & 9.711 \\
\hline $\mathbf{X 8}$ & $\begin{array}{l}\text { I seek to enhance the confidence of } \\
\text { others in setting up personal projects. }\end{array}$ & 4.09 & .801 & 81.8 & 7.506 \\
\hline $\mathbf{X 9}$ & $\begin{array}{l}\text { I have the ability to guide achievement of } \\
\text { goals with distinction and overcoming } \\
\text { obstacles. }\end{array}$ & 4.13 & .942 & 82.6 & 6.757 \\
\hline $\mathbf{X 1 0}$ & $\begin{array}{l}\text { I have the intention and the will to seek } \\
\text { opportunities. }\end{array}$ & 4.38 & .907 & 87.6 & 8.576 \\
\hline \multicolumn{2}{|c|}{ General average of entrepreneurship intention } & 4.18 & .808 & 83.6 & 8.388 \\
\hline Y11 & $\begin{array}{l}\text { I take the responsibilities to risk related } \\
\text { to exploiting opportunities. }\end{array}$ & 3.74 & 1.128 & 74.8 & 5.376 \\
\hline Y12 & $\begin{array}{l}\text { I have the ability to respond quickly to } \\
\text { the available opportunities. }\end{array}$ & 3.78 & 1.208 & 75.6 & 5.323 \\
\hline Y13 & $\begin{array}{l}\text { I keep pace with technical developments } \\
\text { in the aspect of education. }\end{array}$ & 3.82 & 1.158 & 76.4 & 5.863 \\
\hline Y14 & $\begin{array}{l}\text { I adapt to all environmental factors and } \\
\text { variables. }\end{array}$ & 4.27 & .634 & 85.4 & $\begin{array}{c}11.42 \\
8\end{array}$ \\
\hline Y15 & $\begin{array}{l}\text { I encourage the completion of projects } \\
\text { and activities and realize that they will } \\
\text { achieve outstanding success. }\end{array}$ & 3.84 & 1.114 & 76.8 & 6.202 \\
\hline \multicolumn{2}{|r|}{ General average of daring behavior } & 3.89 & 1.048 & 77.8 & 6.83 \\
\hline \multicolumn{2}{|c|}{ General average of Learning entrepreneurships } & 4.14 & .86 & 82.94 & 8.676 \\
\hline
\end{tabular}

Testing study hypotheses:

\section{Analyzing correlation hypotheses:}

Table (7) indicates the correlations between the leadership soft skills and learning entrepreneurships collectively. The value of correlation is $\left(.675^{* *}\right)$ at the level of significant (0.01). Moreover, table (7) shows a positive correlation between the dimensions of leadership soft skills and learning entrepreneurships. According to the results, the strongest correlation is between team building skills and learning entrepreneurships as the correlation coefficient is equal to $\left(.642^{* * *}\right)$ at the level of significance (0.01). However, the weakest correlation is between the communication skills and learning entrepreneurships as the correlation coefficient is equal to $\left(.388^{* * *}\right)$ at the level of significance (0.01). Consequently, accepting the first main hypothesis and the four sub-Hypotheses of the first main hypothesis. 
Table (7) analyzing the correlation between study variables

\begin{tabular}{|l|c|c|}
\hline \multicolumn{1}{|c|}{ Variables } & $\begin{array}{c}\text { learning } \\
\text { entrepreneurship }\end{array}$ & Sig. \\
\hline Leadership soft skills & $\mathbf{. 6 7 5}^{* *}$ & $\mathbf{( . 0 0 0 )}$ \\
\hline Communication skills & $\mathbf{. 3 8 8}^{*}$ & $\mathbf{( . 0 1 2 )}$ \\
\hline Initiative skills & $\mathbf{. 6 0 1}^{* *}$ & $\mathbf{( . 0 0 0 )}$ \\
\hline Training skills & $\mathbf{. 6 3 9}^{* *}$ & $\mathbf{( . 0 0 0 )}$ \\
\hline Team building skills & $\mathbf{. 6 4 2}^{* *}$ & $\mathbf{( . 0 0 0 )}$ \\
\hline
\end{tabular}

Correlation is significant at the 0.01 level (2-tailed)*

Correlation is significant at the 0.05 level (2-tailed)*

\section{Analysis the effect between the study variables:}

Table (8) presents an analysis of the effect of leadership soft skills on learning entrepreneurship using the following decision base in the hypothesis testing: the null hypothesis (Ho) is accepted if the calculated $T$ value is less than the $\mathrm{T}$ tabular value and the significant value is greater than (0.05). Further, the null hypothesis (Ho) rejected if $\mathrm{T}$ calculated value is greater than the $T$ tabular value, and the significant value is less than (0.05). Table (8) shows that there is an effect of leadership soft skills on learning entrepreneurships. This result is supported by the calculated value of $\mathrm{T}$ that reached (5.716) that is greater than the tabular value of $\mathrm{T}$ that equal to (1.684) and at the level of significant (0.05). The value of R2 is equal to (.456) that refers to the ability of leadership soft skills to interpret changes in promoting learning entrepreneurships by (45.6\%). Besides, Table (8) indicates that there is an effect of all the dimensions of leadership soft skills (communication skills, initiative skills, training skills, and team building skills) in promoting learning entrepreneurships. These results is supported by the calculated value of $\mathrm{T}(2,627),(4,694)$, (5.189), (5.232) respectively, which they are greater than the value of $\mathrm{T}$ tabulated that equal to (1.684) at the level of significant (0.05). The effect of team building skills on promoting learning entrepreneurships is the most powerful influencing effects comparing to the other effects since the value of $\mathrm{R}^{2}$ is equal to (.412), which indicates the ability of team building skills to interpret changes in promoting learning entrepreneurships by (45.6\%). On the other hand, the effect of communication skills was the weakest effective relationships, since the value of $\mathrm{R}^{2}$ is equal to (.150) which indicates the ability of team building skills to interpret changes in promoting learning entrepreneurships by (15.0\%). As a result, accepting the second main hypothesis and the four sub-Hypotheses of the second main hypothesis. 
Table (7) analyzing the effect of leadership soft skills on learning entrepreneurship

\begin{tabular}{|l|c|c|c|c|c|c|}
\hline \multicolumn{1}{|c|}{ Variables } & \multicolumn{6}{c|}{ Learning entrepreneurship } \\
\hline Leadership soft skills & $\mathbf{R}^{\mathbf{2}}$ & $\mathbf{S i g .}$ & $\begin{array}{c}\mathbf{F} \\
\text { calculated }\end{array}$ & $\begin{array}{c}\mathbf{T} \\
\text { calculated }\end{array}$ & Beta & B \\
\hline Communication skills & .456 & .000 & 32.675 & 5.716 & .675 & .774 \\
\hline Initiative skills & .150 & .012 & 6.900 & 2.627 & .388 & .436 \\
\hline Training skills & .361 & .000 & 22.029 & 4.694 & .601 & .569 \\
\hline Team building skills & .408 & .000 & 26.922 & 5.189 & .639 & .621 \\
\hline
\end{tabular}

\section{Discussion and conclusion:}

1. The results show that the University of Salahaddin has a high level of leadership soft skills (communication skills, initiative skills, training skills, and team building skills). There is high agreement among study sample on the ability to making dialogue, debate and exchange of views among members of the colleges councils to communicate information, ideas and encouragement and seeking to create the right atmosphere for working as a team to achieve the desired results.

2. The outcomes indicated that the members of the colleges councils University of Salahaddin has a high level of learning entrepreneurship (leadership efficiency, Entrepreneurship intention, and daring behavior) since the responses of the study sample were consistent with a high percentage of the availability of dimensions of learning entrepreneurship. This may be due to the motivation of the members of the collages councils University of Salahaddin and work to adapt with all the factors and environmental variables to reach the completion of activities in an efficient and distinctive way.

3. The results of the statistical analysis showed a positive correlation between the leadership soft skills (communication skills, initiative skills, training skills, and team building skills) collectively and individually in the dimensions of learning entrepreneurship (leadership efficiency, Entrepreneurship intention, and daring behavior).

4. The results of multiple regression analysis demonstrated a significant effect of soft leadership soft skills collectively and individually in learning entrepreneurship. The impact of team building skills on learning entrepreneurship reached the strongest influencing relationships, while the impact of communication skills on learning entrepreneurship reached the weakest influencing relationships. 


\section{Recommendations:}

1. The need to increase the awareness of individuals in organizations of the importance of leadership soft skills representing through the four dimensions (communication skills, initiative skills, training skills, and team building skills) that has a positive effect on promoting the level of learning entrepreneurship.

2. Need to pay more attention to activate the leadership soft skills in practice that has a significant role in increasing the level of learning entrepreneurship through communication with the organizations' employees by making dialogue, discussion, exchange of views and the ability to communicate ideas to others.

3. The need to seeking exploits and adopts unexploited opportunities and creating the right environment for working as a team for the purpose of improving performance and achieving objectives.

4. The need to pay more attention to the committees' recommendations and rely on the approach of the task forces and encourage others to work in the spirit of the team as a means to reach collective decisions.

5. Employees of organizations should be willing to participate in training programs in order to have the expertise required to achieve unique achievements.

6. The need to work to guide the achievement of the objectives of excellence and overcoming obstacles and the ability to respond quickly to the opportunities available. Further, encouraging others to complete projects and activities and realizing they will achieve outstanding success.

\section{References:}

- Abdullah, J. A. and Abdul Rahman, A. Z. (2012), Analysis of the role of personal skills in the dimensions of self-marketing, Journal of Kufa University, No. 23.

- Abrar, A. \& Kwong, C. (2012), Entrepreneurial Learning and Emergence Dynamic Capabilities: A case of Women Entrepreneurs in Creative Industries of UK, International Entrepreneurship Forum Kuala Lumpur Malaysia, 3-6 September.

- Abrar, A., Rauf, A. \& Gohar, M. (2011), Conceptualization Gender and Entrepreneurial Learning, BAM Conference: Building and Sustaining High Performance Organization in a Challenging Environment 13-15 September, Aston University Birmingham.

- Akrawi, J. S (2002) The Role of Empowerment in Enhancing Organizational Creativity, unpublished $\mathrm{PhD}$ thesis, Faculty of Management and Economics, Mosul University, Iraq.

- Al-Mahamda, M. M. (2015) The Relationship between Parental Leadership and Organizational Commitment: An Applied Study on the General Directorate of Municipalities in Dohuk Governorate, Kurdistan Region, Iraq, Unpublished Master Thesis, Mansoura University, Egypt.

- Awan, M. H., Ahmes, K. \& Zulqaenain, W. (2015) Impact of project Manager's Soft Leadership Skills on Project Success, journal of poverty, Investment and Development, No. (8).

- Azim, S., Gale, A. \& Lawlor-Wright, T. \& Kirkham, R. \& Khan, A. \& Alam, M. ,(2010), The importance of Soft Skills in Complex Projects, Internet J. Managing Projects Business, Vol. (3), No. (3).

- Balachander, S. \& Jayam, R. (2015), A Study on the "Soft Skill Requirements "and Suggested Training for Student Community at Colleges in today's Context, International, journal of management and Social Science Research Review, Vol. (1), No. (10).

- Brungardt, C. (2011), The Intersection between Soft Skill Development and Leadership 
Education, journal of Leadership Education, Vol. (10), No. (1).

- Cole, M. A., (1999), Become the Leader Followers Want to Follow, Journal of Supervision, Vol. (60), No. (12).

- Hajjaj, O. N. (2014) the Role of Soft Skills in the enhance the Administrative Jobs: An Empirical Study on Administrative Jobs in Gaza, Unpublished Master Thesis, Faculty of Commerce, Islamic University-Gaza, Palestine.

- Hussein, Y. (2010) Technological Leadership and its Impact on the Structure of International Trade, 10th Annual International Scientific Conference: Leadership in the Knowledge Society, Faculty of Economics and Administrative Sciences, Al-Zaytoonah university, Jordan.

- Inyang, B. J. \& Enuoh, R. O. (2009), Entrepreneurial Competencies: The Missing Links to Successful Entrepreneurial in Nigeria, International Business Research, Vol. (2), No. (2).

- Keskes, I. (2014), Relationship Between Leadership styles and Dimensions of Employee Organization Commitment, University Polytechnic De Catalonia, Spain, Vol. (10), No. (1).

- Levasseur, R. E., (2013), People Skills: Developing Soft Skills $-\mathrm{A}$ Change Management Perspective, J. Informs. Walden University, Vol. (43), No. (6).

- Marques, J. (2013), Understanding the Strength of Gentleness: Soft-Skilled Leadership on the Rise J Bud Ethics, journal of Business Ethics is the property of Springer Science \&Business Media , No. (116).

- Mckenna, E. (2000), Business Psychology and organization Behaviour a Student's Handbook, (USA: Psychology Press, Taylor and Francis Group).

- Moin, R. \& Biswal, S. (2012), Soft Skills in Status QUO, International Journal of Physical and Social Sciences, Vol. (2), No. (15).

- Moustaghfir, K. \& Sirca, N. T. (2010), Entrepreneurial Learning in higher Education: Introduction to the thematic Issue, International journal of Euro - Mediterranean Studies, Vol. (3), No. (1).

- Nikitina, L. \& Furuoka, F. (2011), Sharp focus on Soft Skills: A Case Study of Malaysian
University Students Educational Expectations, Journal of Springer, Vol. (10), No. (4).

- Rae, D. (2006), Entrepreneurial Learning: a Narrative-based Conceptual Model, journal of Small Business and Enterprise Development, Vol. (12), No. (3).

- Rao, M.S., (2013), Soft Leadership: A New Direction to Leadership, Journal of Industrial and Commercial Training, Vol. (45), No. (3).

- Rongraung, S., Somprach, K., Khanthap, J. \& Sitthisomjin, J. (2011), Soft Skills for Private Basic Education Schools in Thailand, Elsevier, Journal of Procedia - Social and Behavioural Sciences, No. (112).

- Samah, S. and Mourad, M. (2010) Human Capital and entrepreneurship Creativity Industry, 10th Annual International Scientific Conference: Leadership in the Knowledge Society, Faculty of Economics and Administrative Sciences, Al-Zaytoonah university, Jordan.

- Sarwoko, E. \& Surachman, A. \& Djumilah, H. (2013), Determinants of Business Performance in SMEs, IOSR journal of Business and Management, Vol. (7), Issue. (3).

- Shahid S, Asiahbinti M. (2012), The Importance of Soft Skill for Leader, 1st International Conference on Innovation and Technology for Sustainable Built Environment, 16-17 April 2012, Perak, Malaysia.

- Shahid, S., Asiahbinti M. (2011), A Study on Perceived Leadership Soft Skills, Trustworthiness and Structure Empowerment of Deans in The Three Malaysian Public Universities, $\mathrm{PhD}$ thesis, University Saints Malaysia.

- Simpson H. A., (2013), Public Administration in today's World Organization and Markets, Journal ofPolitical Science Politics, Vol. (33), No. (4).

- Solan, Z. \&Ruppin, E., (2001), Similarity in Perception: A Window to Brain Organiztion, Journal of Cognitive Neuro Science, (13).

- The Relationship between Parental Leadership and Organizational Commitment: An Empirical Study on a Public Directorate of Municipalities in Dohuk Governorate, Kurdistan Region, Iraq, Master Thesis, Mansoura University, Egypt.

- Zidan, A. A. (2007) Entrepreneurship the Driving Force of National Economies, Arab 
(JPMNT) Journal of Process Management - New Technologies, International Vol. 7, No 1, 2019.

Organization for Administrative Development,

Research and Studies, Egypt. 